\title{
PDIA3 Gene
}

National Cancer Institute

\section{Source}

National Cancer Institute. PDIA3 Gene. NCI Thesaurus. Code C112118.

This gene is involved in both antigen presentation and formation of disulfide bonds in proteins. 